\title{
The perspectives of family policy in Russia amid increasing cohabitation
}

Ekaterina Mitrofanova, National Research University Higher School of Economics Alyona Artamonova, National Research University Higher School of Economics

\begin{abstract}
Russia has long been characterized by early and universal marriage. After the Soviet Union collapse, the average age of marriage has been rising, and cohabitations have become common. Many scholars explain the causes of this trend through the perspective of the Second Demographic Transition. The aim of this research was to define the nature of cohabitations in Russia, reveal the factors of entrance to non-marital unions in order to discuss how and why non-marital union is implicated in recent dialogues about family policy. In order to achieve the aim, such methods as Event History Analysis and Sequence Analysis were used.

Cohabitation is not a complete alternative to marriage in Russia yet, but the proportion of Russians from various social strata for whom cohabitation does not grow into a marriage is on the rise. Young, non-religious, educated people from big cities have started to consider non-marital union appropriate for childbearing and childrearing. It demonstrates that cohabitation is close to becoming an independent social institution which is a trend of great concern to policymakers due to its implications for children's well-being.
\end{abstract}

\section{Keywords}

First matrimonial unions; life course; family policy; Event History Analysis; Sequence Analysis.

\section{JEL classification}

J12; J13; J18; C23. 


\title{
Introduction
}

Modern social demographic policy of Russia is focused on family, which is founded upon the unit of the married couple. Here is a quote from the Concept of Demographic Policy of Russia to 2025:

\begin{abstract}
The solution of strengthening the family institution, the revival of spiritual and moral values of family relations includes: <..> propaganda on the values of families with more than one child, different forms of family placement of children without parental care - with the aim of creating a positive image of family in society with stable registered marriage of spouses - and having several children or adopting children without parental care.
\end{abstract}

The quote shows that the modern family - which is not always based on stable marriage - is changing; and these transformations are ignored by lawmakers. Moreover, the changes in matrimonial behaviour are not accepted as a normal stage of development of the society, but are ignored and even demonized. More often there are such alarmist statements declaring family and family values to be in crisis, that there is an evident call to revive traditional values (although the meaning of these words is rarely explained).

Instead of listening to the people and equalizing the rights and opportunities of registered and non-registered couples, lawmakers offer to increase the importance of marriage and neglect cohabitation. For example, in April 2015 in Rossiskaya Gazeta ${ }^{1}$, the proposal of one lawyer was published; in it, he claimed that, after two years from the beginning of cohabitation, such a living arrangement should be recognized as a marriage. The intended goal was the protection of financial rights of partners holding property jointly. Nevertheless, the selected way to achieve the goal is rather questionable. To explain why, the experience of countries with totalitarian regimes (that proclaimed their high birth rate) shows that the birth rate is falling rapidly after the regime change. The experiences of anti-alcohol campaigns (including Russian ones) show that, as soon as anti-alcohol campaigns end, the death rate from alcoholic poisoning increases dramatically and life expectancy falls. These, and many other examples, show that any interventions into the private lives of people by the government and the imposition of specific behaviour models may have negative consequences in the long term. The initiative of the transformation of cohabitations into marriage after two years constitutes not only the invasion of privacy of individuals, but also the attempt to make responsible decisions for people. If people decide not to marry, then such a decision constitutes a personal choice that should be considered not only at the level of society (which has already been happening for 20 years), but also at the government level.

This article provides empirical evidence that Russia tends to have more cohabitations, and that these appendages of marriage turn into full-fledged matrimonial couples, in which children are born and raised. Which social and psychological factors stand behind the choice of this living arrangement is a question for future research. This work aims to draw attention to the fact that such choices are made: the amount of cohabitations, which will not result in a marriage, but which are stable and fit for childbearing, is increasing. We should stop ignoring this phenomenon (i.e. recognizing only marriages) and give it due consideration in legislation - not to transform cohabitations into marriages forcibly, but to equate their statuses at the legal level. It is necessary to expand the conceptualization of the family, without ignoring those people who have chosen alternative marriage forms.

\footnotetext{
1 Rossiskaya Gazeta. Cohabitation is going to become equal with marriage (http://www.rg.ru/2015/04/29/brak.html).
} 


\section{Marriages and cohabitations in Russia}

The study of the transformation of matrimonial behaviour in a population is an area of sociological and demographic research, the results of which help to explain changes in society and take part in improving family and demographic policy. This study is conducted to trace the dynamics of marriage and partnership formation by using the example of Russian generations which were socialized before the collapse of the Soviet Union (Levada, 2005) calls these generations Soviet) and after it (post-Soviet or modern generations).

After the collapse of the USSR, all spheres of Russian society have undergone changes (although Russia had relatively low marital age and strong institute of marriage) that have led, since 1993, to the rise of average marital age; there was an increase in the number of unregistered couples, and the average age of people in these couples was decreased. Such changes in the culture of marital and partnership behaviour of the youth were regarded by demographers as the evidence of a Second Demographic Transition occurrence in our country, where unmarried couples became an alternative to marriage.

What are these unions - a preparatory stage before marriage or an independent social institution? What segments of a population prefer to live in unregistered relationships? For how long are such relationships stable and strong? Are they suitable for birth and parenting? In this article we present the most relevant and empirically supported answers to these questions. But first we will address terminology.

Among all the variety of terms for the unregistered relations between people, there are correct terms (e.g. cohabitation, partnership, consensual marriage, an unregistered marriage, the actual marriage) and incorrect terms (e.g. common-law marriage). All of these terms (except partnership) are synonyms and presuppose that individuals are living together, but cohabitation is the most concise, intuitive term and therefore is often used in demographic studies. This term has not caught on in society, because the word cohabitant has a negative connotation; the term is, however, accepted in science, so we will use it in our study.

The main theoretical framework of this study is the conception of the life course. In sociology, the life course is studied as a development process, culturally constructed life stages and roles related to them (Elder and Glen, 1975; Mayer, 2009; Mills, 2000). The life course is a chain of phases of life which acquire different meanings in the process of socialization of the individual. In this sense, sociologists are studying periods of the human life from childhood to old ages, dividing them into different spheres: family, education and work. This study is focused on family at the beginning of marital or partnership trajectory.

In recent decades, the life courses of Russians (which was standardized before the 1960s) were supplemented by characteristics such as the fundamental openness and diversity of individual maneuvers. Matrimonial behaviour ceased to be independent from sexual and reproductive incentives, as it was earlier under the traditional model of demographic behaviour (Zakharov, 2008). Marriage has been replaced by alternative forms of coresidence. The most common is cohabitation (Avdeev and Monnier, 2000). In many Western European countries, cohabitation ceased to be a form of deviant behaviour a long time ago; thus, it has been studied there far longer than in Russia. There are a few theories explaining the spread of cohabitations, but the main one is the theory of the Second Demographic Transition, developed by R. Lesthaeghe and D. Van de Kaa (1986). The researchers believe that it much better describes the changes in matrimonial behaviour than other theories. This point of view, strengthened after the publication of the study by Gerber and Berman (2010) which proved empirically that, rather 
than the lack of good economic conditions, the focus on self-development and independence contribute to the spread of cohabitation.

The Second Demographic Transition is bounded by fundamental shifts in the life course of the individual. The freedom of choosing a marriage partner and a living arrangement are more expansive, and approaches to the consequences of sexual relations are more responsible than earlier. The emergence of contraception and more careful life planning enhances individuals' ability to control their destinies. A fixed sequence of events in individual biography was replaced by a variety of life courses (Lesthaeghe and Van de Kaa, 1986).

Thinking about these changes on the value-normative level, Giddens (2003: 66) describes family and marriage as shell institutions, pointing out that the names remained the same, but the main inner content has changed. In the traditional family, which was an economic unit, the married couple was only a part of the structure, with communication with children and other relatives being more important. This structure was replaced by a couple, not necessarily married, but is based on romantic love and sexual attraction; such a unit became the main component of family life. As Giddens writes, the most correct current definition of what is happening in private life is the formation of couples and their break ups, rather than marriage and family creation.

Mills and Blossfeld (2013) have supplemented the theory of the Second Demographic Transition with the theory of globalization. This complex approach shows that cohabitation is a 'combination of emotional and physical intimate relations that mean living together and existing without legal or religious sanctioning'. Cohabitation is becoming an independent institution (common among young people) which is more oriented on acquiring education and selfdevelopment, but not on family creation in conditions of increasing uncertainty caused by globalization and world economic problems.

Pluralism of forms of marital and reproductive behaviour, coupled with a rising general level of education of women and the advent of modern contraception, has led to the postponement of first births at a later age or not having children. As a result, young people prefer to enter into cohabitation as a union, not always involving the legitimation of relations in the future, but providing some of the benefits of marriage, including the ability to have a common budget. In many relationships, the flexibility of unregistered unions responds to the need of reducing the high level of economic and political uncertainty.

According to the research of a group of theorists working under the guidance of Kierman, who compared matrimonial behaviours in a number of countries ${ }^{2}$, cohabitation during its diffusion goes through four 'evolutionary stages': innovation, popularization, legitimation, and habitualization (Kiernan, 2002; Sobotka and Toulemon, 2008; Matyasiak, 2009). In the first stage, non-marital unions are few and are found only among people with low income. In the second stage the practice of cohabitation becomes more common, and it can be found in almost all social layers, yet these unions remain short (marriages are still longer than cohabitations), are considered as the first step to marriage and regarded as inappropriate for childbirth and parenting. In the third stage, unregistered unions start to be considered as an alternative to marriage, the duration of which is equal to marriage and is quite suitable for parenting. In the last stage, cohabitations merge with marriages and efficiently perform all its functions. The structuring of the stages is presented in Table 1.

2 Albania, Austria, Belgium, Bulgaria, Finland, France, Germany, Hungary, Italy, Poland, Romania, Russia, Slovakia, Spain, Sweden, the Czech Republic, the Netherlands, Ukraine, the United States, etc. 
Table 1. The stages of the spread of cohabitation

\begin{tabular}{|c|c|c|c|c|}
\hline \multirow[b]{2}{*}{ Features } & \multicolumn{4}{|c|}{ Stages } \\
\hline & $\begin{array}{l}\text { 1. Innovation } \\
\text { (cohabitation } \\
\text { as marginal } \\
\text { phenomenon) }\end{array}$ & $\begin{array}{l}\text { 2. Popularization } \\
\text { (cohabitation as a } \\
\text { prelude to } \\
\text { marriage) }\end{array}$ & $\begin{array}{l}\text { 3. Legitimization } \\
\text { (cohabitation as a } \\
\text { substitute for } \\
\text { marriage) }\end{array}$ & $\begin{array}{l}\text { 4. Habitualization } \\
\text { (cohabitation and } \\
\text { marriage are } \\
\text { indistinguishable) }\end{array}$ \\
\hline Diffusion & $\begin{array}{l}\text { is practiced by } \\
\text { marginal } \\
\text { groups of } \\
\text { society }\end{array}$ & \multicolumn{3}{|c|}{ spreads among persons from the various social strata } \\
\hline Permanency & \multicolumn{2}{|c|}{$\begin{array}{l}\text { short duration or a short pre-marital } \\
\text { experience }\end{array}$} & \multicolumn{2}{|c|}{$\begin{array}{l}\text { lasts longer and is less likely to be } \\
\text { converted into marriage }\end{array}$} \\
\hline $\begin{array}{l}\text { Cohabitation as a } \\
\text { family } \\
\text { arrangement }\end{array}$ & \multicolumn{2}{|c|}{ pregnancy is a reason for marriage } & \multicolumn{2}{|c|}{$\begin{array}{l}\text { parenthood becomes more and more } \\
\text { common among cohabiting couples }\end{array}$} \\
\hline
\end{tabular}

Russia, as a country of the Eastern Bloc, demonstrates demographic outcomes of the Second Demographic Transition (SDT) in an atypical fashion. In terms of destandardized family forms, Russians began to perceive cohabitation as an alternative to marriage (Mills et al., 2013). Growing cohabitation rates alongside declining marital rates emerged in the Soviet Union in the middle of the 1980s, years before the fall of socialism (Gerber and Berman, 2010). Zakharov (2008) showed that the birth cohorts from the 1970s already started to postpone entry unions and demonstrate all features of SDT. Mills clarified that non-marital union in Russia in the long run is a signal of low education and limited financial capital that is more common for the United States than for Europe (Mills et al., 2013).

The purpose of this study is to identify factors of people's entry to cohabitations and to ascertain whether this type of union is an independent institution, which functions in the same way as marriage.

We suppose that, in Russia, cohabitation is on the transition stage from popularization to legitimation; what this means is that it is not only exclusive to people with low income (as was shown in previous research (Zakharov, 2008)) and shorter than marriage, but also still inappropriate for childbirth and parenting.

We hypothesize that:

1. Cohabitations are spread mainly among those of young generations who are non-religious, are living in big cities and have a secondary education;

2. Conception causes marriage as the first union or the transition from cohabitation to marriage;

3. The most common statuses for the modern generations are: single at the age of 15 , cohabiting without children by the middle of the observed age window, married with at least one child by the age of 35 (was conceived being married).

To test these hypotheses, we decided to apply methods used in life course sociology: Event History Analysis and Sequence Analysis. The use of these methods is possible only with longitudinal data and retrospective surveys.

\section{Database}

As the empirical base of the study, the panel part of the Russian part of the Generations and Gender Survey (GGS) $(2004,2007,2011)$ and data from the survey Person, Family, Society (PFS) survey (2013) were selected. ${ }^{3}$ Both surveys

\footnotetext{
${ }^{3}$ The Russian part of GGS is 'Parents and Children, Men and Women in Family and Society'. The three waves of the survey were conducted by the Independent Institute for Social Policy (http://www.socpol.ru/eng/research_projects/proj12.shtml).
} 
are retrospective and representative for Russia. It should be noted that the difference in years of the surveys is not very big - we would otherwise be able to compare the results. At the same time, coverage generations in surveys still differ: this provides an opportunity to supplement the data of the GGS survey (mainly reflecting the behaviour of the Soviet generation of Russians) using the data from the PFS survey (the sample of this research consists predominantly of the younger generation representatives). General information about the databases can be found in Table 1.

Table 1. The GGS and PFS databases features

\begin{tabular}{c|cc}
\hline & GGS & $P F S$ \\
\hline Years of the surveys & 3 waves: 2004, 2007, 2011 & 2013 \\
Number of respondents & 4948 cases & 3572 cases \\
Generations & $1935-1984$ years of birth & $1975-1994$ rr. years of birth \\
Age of respondents & $24-85$ & $18-44$ \\
\hline
\end{tabular}

In order to complete the tasks of this study, we have to impose some restrictions on the data. One of the restrictions relates to the sequence of matrimonial events. It is necessary to consider only the first unions for understanding the nature of cohabitation in Russia. This localization allows for a better understanding of generational differences in the beginning of matrimonial and reproductive trajectories of respondents. Young generations choose new models of behaviour associated with marital or partnership spheres: they are focused on the emotional sphere of relations, hedonistic context and, accordingly, are not in a hurry to start a family and have children. In addition, the majority of Russians in their life are limited only by the first unions.

Another restriction concerns the lower and upper age limits of respondents, who fall into the sub-sample to build some models. 15 years - the lower age limit - was taken as the age of beginning of reproductive behaviour. In the GGS sample there are representatives of five generations, the youngest respondents at the time of the third survey wave were 25 years old. There is an even younger generation in the PFS. To understand the changes, which happened to the matrimonial behaviour of Russians, one should equalize the chances of the representatives of all generations to entry to the first union. After considering several options for establishing the upper age limit, we decided on the age of 35 years, as this will help to avoid the influence of atypical ages of entry to first unions of older generation representatives, but at the same time maintain the age structure of the sample.

\section{Analysis of the occurrence of matrimonial events}

The first group of models focuses on the identification and comparison of factors of entry to cohabitation and marriage as first unions (Models 1 and 2). The second group of models describes how the conception is associated with the following events: entry into cohabitation and marriage as first unions (Models 3 and 4) and entry into marriage after the experience of living together (Model 5).

\section{The first group of models}

The beginning of matrimonial trajectories belonging to the first group of models, presented in Figure 1. 
Figure 1. Marital-partnership trajectories for Models 1 and 2

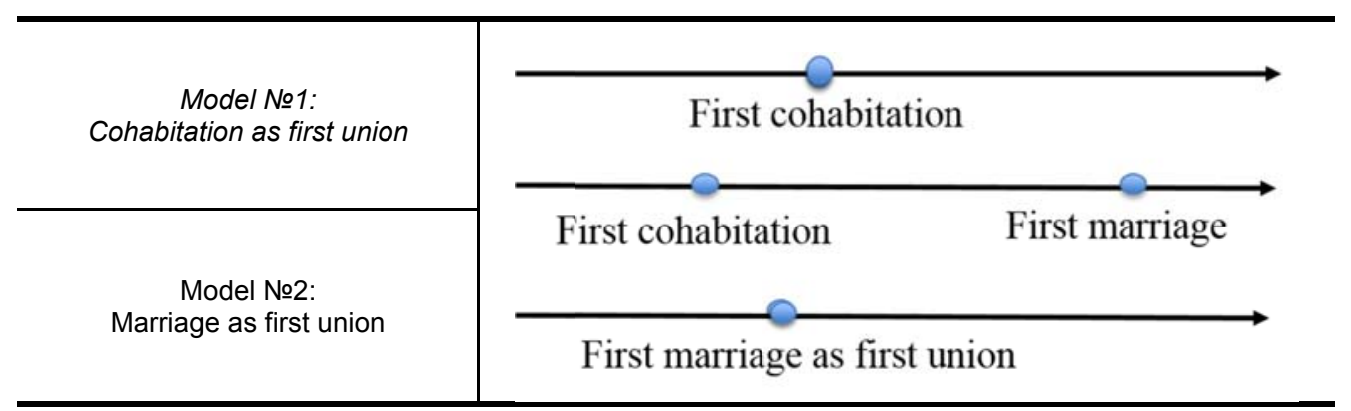

For the model which identifies factors of entry into cohabitation as the first union, two options are suitable: (1) when the respondent was throughout his or her life in the first cohabitation and not married, and (2) when the individual had at least one marriage after the cohabitation. For the model, identifying the factors of marriage as first unions, it is necessary that a marriage was not preceded by a cohabitation. Specification of Models 1 and 2 are presented in Table 2.

Table 2. Basic characteristics of Cox regressions for Models 1 and 2

\begin{tabular}{|c|c|c|}
\hline \multirow[b]{2}{*}{ Elements of model } & \multicolumn{2}{|c|}{ Cox Regressions for Models } \\
\hline & $\begin{array}{c}\text { № } 1 \\
15 \text { years }-1^{\text {st }} \text { cohabitation }\end{array}$ & $\begin{array}{c}\text { № } 2 \\
15 \text { year }-1^{\text {st }} \text { direct marriage }\end{array}$ \\
\hline Event & \multicolumn{2}{|c|}{ Entry into first union } \\
\hline Subject & \multicolumn{2}{|c|}{ Russians at the age of $15+$ years } \\
\hline Dependent variable (time) & $\begin{array}{l}\text { Months from } 15 \text { years to entry } \\
\text { into } 1^{\text {st }} \text { cohabitation }\end{array}$ & $\begin{array}{l}\text { Months from } 15 \text { years to entry into } \\
\qquad 1^{\text {st }} \text { marriage }\end{array}$ \\
\hline $\begin{array}{c}\text { Predictors } \\
\text { Stratifying variable }\end{array}$ & \multicolumn{2}{|c|}{$\begin{array}{c}\text { Sex } \\
\text { Place of residence } \\
\text { Level of education } \\
\text { Religiosity } \\
\text { Generations }\end{array}$} \\
\hline
\end{tabular}

Table 3 presents the relative number of observations for all the variables included in the analysis. The generational structure of the GGS survey corresponds to the age structure of the population of Russia, which is dominated by people born from 1945 to 1975 . The PFS Survey is aimed to identify features of the behaviour of young Russians. To account for the difference in matrimonial behaviour of men and women, the variable Sex was included to the model. According to the data obtained by the Russian National Population Census 2010, the proportion of women is 54 per cent of the population. The data array of the GGS panel has a serious displacement towards women. Recounting of the array of all the panel waves was not made because the estimation of the displacement of the panel as a result of respondent attrition is not possible. The array PFS data was not recalculated because their divergence from the general population can be considered negligible. 
Table 3. The relative number of observations for the predictors of the first group of models, \%

\begin{tabular}{c|ccc}
\hline $\begin{array}{c}\text { Predictors of } \\
\text { models }\end{array}$ & Categories of variables & GGS & PFS \\
\hline \multirow{5}{*}{ Generations } & $1935-1944$ & 16.8 & - \\
& $1945-1954$ & 21.4 & - \\
& $1955-1964$ & 26.8 & - \\
& $1965-1974$ & 21.4 & - \\
& $1975-1984$ & 13.5 & 48.1 \\
\multirow{4}{*}{ Sex } & $1985-1994$ & - & 51.9 \\
& Male & 32 & 49 \\
& Female & 68 & 51 \\
& Urban area & 56.8 & 40.1 \\
Level of education & Rural area & 43.2 & 59.9 \\
& Higher & 22.3 & 33.8 \\
Religiosity & Secondary general & 54.6 & 37.6 \\
& Secondary vocational & 23.1 & 28.6 \\
\hline
\end{tabular}

To control for the impact of the environment on respondents' behaviour, we included the variable Type of the settlement. In the case of the GGS panel, this figure was taken at the time of the third wave (2011). Migration mobility of population in Russia is low, so the use of the current settlement type can only slightly shift the overall estimations. GGS largely covers the urban population, while in the array of the PFS, the rural population accounts for more than half of the respondents.

Regarding the level of education, in the array of PFS surveys - which represents the young population of Russia - in comparison with GGS there is a higher proportion of people with higher education and a lower share of people with secondary education.

The binary variable religiosity is created in order to manage the religiousness of the respondents with the categories "confess one religion" (religious) and "do not profess any religion" (non-religious). In the PFS there is a much smaller percentage of people belonging to the believers than in GGS.

All variables were subjected to a correlation analysis, which showed that the variables are independent and can be included in the model.

\section{Results of the analysis of the first group of models}

Basic characteristics of the models indicate that at least one of the variables explains the change of the dependent variable, which means that it is associated with the risk of an onset of cohabitation or marriage. The significance of almost all coefficients does not exceed 5 per cent, that is, they are statistically significant. The coefficients of Model 1 are presented in Table 4. 
Table 4. Cox regressions for Model №1: The risk to enter into a first cohabitation after the age of 15

\begin{tabular}{|c|c|c|c|}
\hline \multirow{2}{*}{ Predictors of models } & \multirow[t]{2}{*}{ Categories of variables } & $\begin{array}{c}\text { GGS: } \\
1444 \text { events }\end{array}$ & $\begin{array}{c}\text { PFS: } \\
1925 \text { events } \\
\end{array}$ \\
\hline & & \multicolumn{2}{|c|}{ Models coefficients $\operatorname{Exp}(B)$} \\
\hline \multirow{3}{*}{ Gender } & Male & \multicolumn{2}{|c|}{ Ref. group } \\
\hline & Female & $1,18^{* * *}$ & $1,26^{* * *}$ \\
\hline & Higher & \multicolumn{2}{|c|}{ Ref. group } \\
\hline \multirow[t]{2}{*}{ Level of education } & Secondary general & $1,65^{\star \star *}$ & $1,15^{\star * *}$ \\
\hline & Secondary vocational & $1,44^{\star \star *}$ & $1,15^{\star * *}$ \\
\hline \multirow{2}{*}{ Place of residence } & Urban area & \multicolumn{2}{|c|}{ Ref. group } \\
\hline & Rural area & $0,73^{* * *}$ & 0,94 \\
\hline \multirow{2}{*}{ Religiosity } & Non-religious & \multicolumn{2}{|c|}{ Ref. group } \\
\hline & Religious & $1,41^{* * *}$ & $1,13^{* * *}$ \\
\hline
\end{tabular}

In accordance with Model 1, the probability of women to engage in an unregistered union is about 1.2 times higher than of men of the same ages. This is due to the fact that women enter unions at an earlier age than men. The chances of both sexes to join a union of any type are aligned at the age of 40 .

The respondents with professional and general education are about 1.5 times (in the case of the GGS respondents) and 1.15 times (in the case of the PFS respondents) more likely to enter into cohabitation than those in the reference group, that is, those with higher education that display a 'pattern of disadvantage' in Russia, as revealed by Mills et al. (2013). If we talk about the type of settlement, rural areas are 0.7 times less likely to enter into cohabitation than those who live in cities (GGS). In the case of younger generations (PFS), the likelihood to start cohabitation for the residents of rural and urban areas are not significantly different. Those who do not refer to themselves as the followers of the existing religions are 1.4 times (GGS) and 1.1 times (PFS) more likely to enter into cohabitation than religious people.

Figure 2. Hazard curves for cohabitation as first union (stratification by generation)

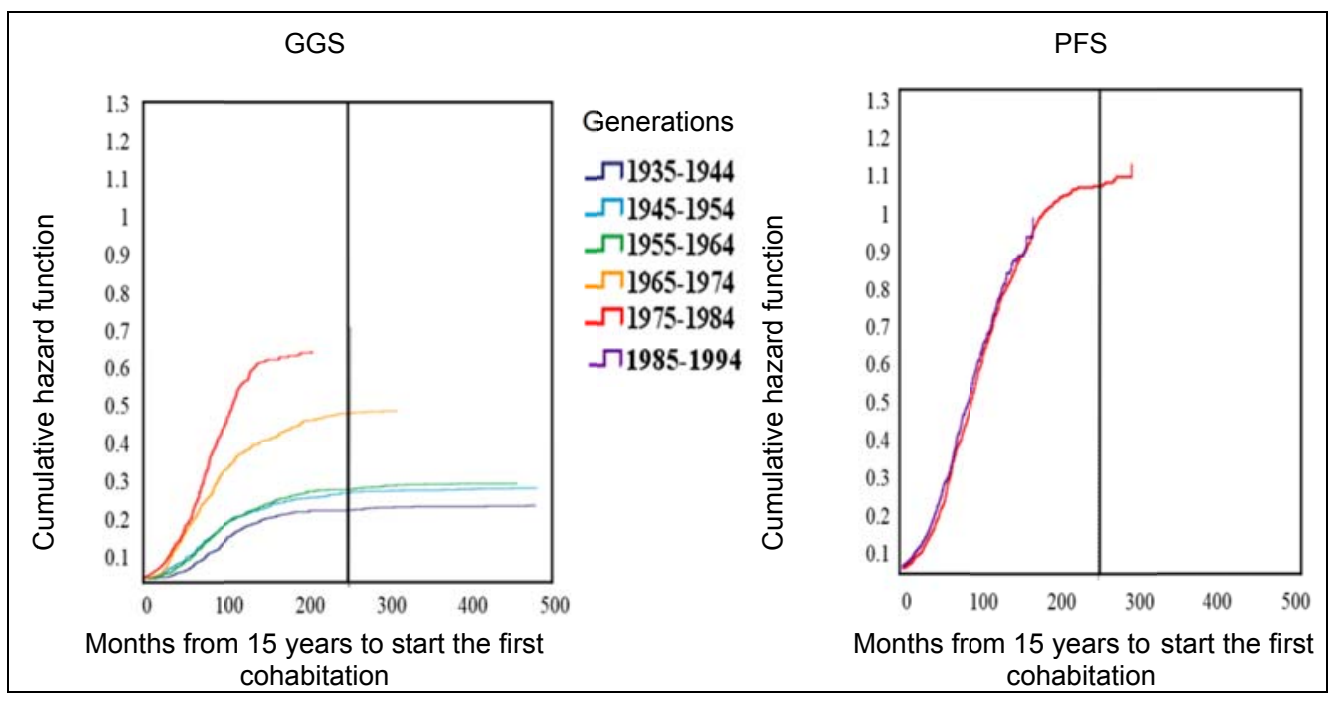

The stratification for all models of the study was the variable Generation. Figure 2 represents the probability function of an entry into marital union for the representatives of each of the six generations for GGS and the two generations for PFS. The younger the generation that an individual represents, the more he or she 
is prone to enter into cohabitation as a first union. The dotted line shows the onset of 35 years. The representatives of the youngest generations have not reached this age; however, we can already assume that the cumulative probability to enter into a first cohabitation will increase for them.

Table 5. Cox regression for Model №2: The probability of entering into a first marriage after the age of 15

\begin{tabular}{|c|c|c|c|}
\hline \multirow[t]{2}{*}{ Predictors of models } & \multirow{2}{*}{$\begin{array}{c}\text { Categories of } \\
\text { variables }\end{array}$} & $\begin{array}{c}\text { GGS: } \\
3135 \text { events }\end{array}$ & $\begin{array}{c}\text { PFS: } \\
\text { 568 events }\end{array}$ \\
\hline & & \multicolumn{2}{|c|}{ Models coefficients Exp(B) } \\
\hline \multirow{3}{*}{ Gender } & Male & \multicolumn{2}{|c|}{ Ref. group } \\
\hline & Female & $1,18^{* * *}$ & $1,55^{\star \star \star}$ \\
\hline & Higher & \multicolumn{2}{|c|}{ Ref. group } \\
\hline \multirow[t]{2}{*}{ Level of education } & Secondary general & 0,96 & $0,78^{\star *}$ \\
\hline & Secondary vocational & $1,10^{\star \star}$ & $1,28^{\star \star}$ \\
\hline \multirow{2}{*}{ Place of residence } & Urban area & \multicolumn{2}{|c|}{ Ref. group } \\
\hline & Rural area & $1,22^{* * *}$ & $1,19^{\star *}$ \\
\hline \multirow{3}{*}{ Religiosity } & Non-religious & \multicolumn{2}{|c|}{ Ref. group } \\
\hline & Religious & $0,79^{\star \star *}$ & $0,69^{\star \star \star}$ \\
\hline & \multicolumn{3}{|c|}{${ }^{*} p=0.10,{ }^{* *} p=0.05,{ }^{* *} p=0.01$} \\
\hline
\end{tabular}

Model 2 was constructed to identify factors of entry into a first marriage without the experience of preliminary coresidence (Table 5). The probability of women to enter into marriage as the first union is more than the same indicator calculated for men of the same age, 1.2 times more for GGS and 1.5 times more for PFS. In the case of the GGS respondents, the probability to enter into marriage without prior cohabitation is loosely associated with the level of education. In the case of PFS, the situation is different: young Russians with higher education are more likely to marry than their peers with general education; however, they are about 1.3 times less likely to register a relationship than their peers with professional education. The probability of marriage of rural residents as the first union 1.2-fold exceeds this indicator, which is calculated for denizens of all generations. Non-religious respondents are about 0.7 times less likely to enter into marriage without prior cohabitation than religious people.

Figure 3. Probability function of entry into first marriage as first union

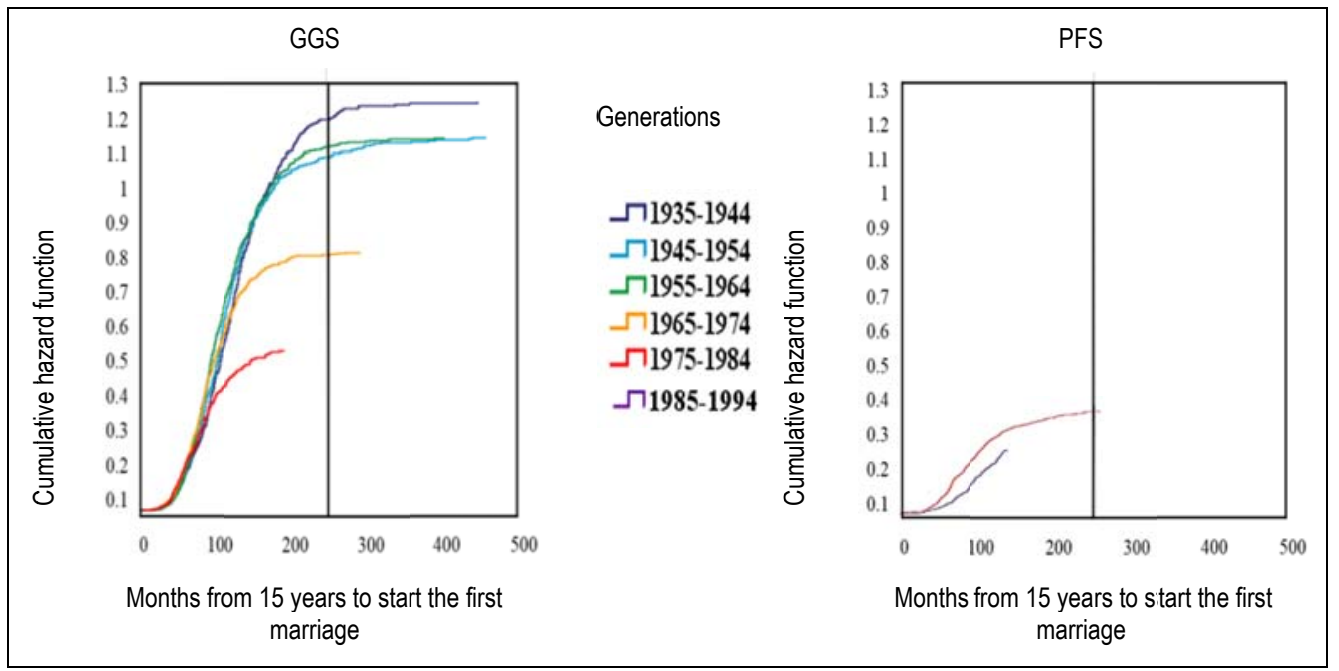

In Figure 3 we see that the respondents from Soviet generations have 3 times higher chances to enter into marriage without prior cohabitation than the representatives of post-Soviet generations. 


\section{The second group of models}

The purpose of the second group of models is to understand whether cohabitation is suitable for parenting or the respondents prefer to formalize their relationships after they have found out about conception (the so-called "marriage after baby"). For this purpose, it was necessary to compare the model of entry into cohabitation and marriage as first unions, as well as marriage after the experience of cohabiting, where conception was an explanatory variable about entry into the analyzed union (Figure 4 and Table 6).

Figure 4. Marital-partnership trajectories and occurrence of conception for Models 3, 4 and 5

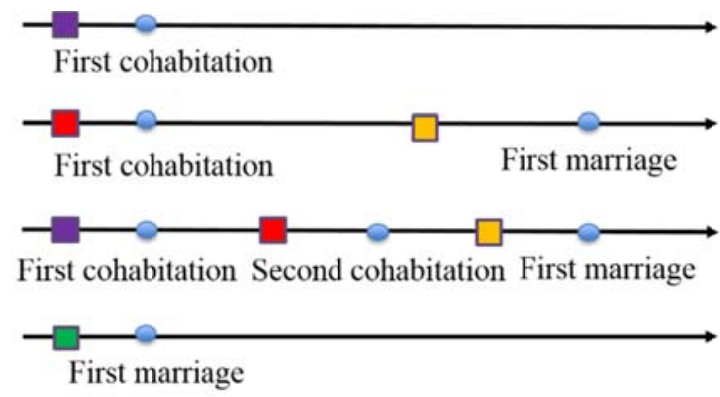

Conceiving for Model 3

Conceiving for Model 4

Conceiving for Model 5

Conceiving for Models 3 and 5

The independent variable was constructed separately for each model to capture the fact of conception occurrence strictly before entry into each of the analyzed unions. For Models 3 and 4 the construction of this variable (the fact of conception marked by purple and green) did not cause any questions.

In the case of Model 5 , because of the lack of information about which partner belonged to one or another union, in a situation where, after conception, the respondent entered into cohabitation and then into marriage (marked in red in the Figure), it is difficult to understand whether conception increases the chances of marriage or cohabitation. It was found that more than 80 per cent of cases between the first conception and marriage were not less than 45 months, which means that the child was at least three years old at the time of marriage after living together, thus conception had stimulated entry into cohabitation instead of into marriage. Because the marriage was not hasty, it is likely that it was intended not to cover childbirth, but to legitimize the rights of the child and family at the legal level. Thus, the conception, which occurs more than 45 months before the marriage, was then considered as the stimulator of cohabitation (Model 3).

Table 6. Initial characteristics of the Cox regressions for Models 3, 4 and 5

\begin{tabular}{|c|c|c|c|}
\hline \multirow{3}{*}{ Elements of model } & \multicolumn{3}{|c|}{ Cox Regressions for models } \\
\hline & №3 & №4 & №5 \\
\hline & $\begin{array}{l}15 \text { years - } 1 \text { st } \\
\text { cohabitation }\end{array}$ & $\begin{array}{c}15 \text { year - } 1^{\text {st }} \\
\text { marriage }\end{array}$ & $1^{\text {st }}$ cohabitation $-1^{\text {st }}$ marriage \\
\hline Event & $1^{\text {st }}$ cohabitation & 1 st direct marriage & $1^{\text {st }}$ marriage after $1^{\text {st }}$ cohabitation \\
\hline $\begin{array}{l}\text { Subject } \\
\text { Dependent variable (time) } \\
\text { Predictors }\end{array}$ & $\begin{array}{l}\text { Russians in } \\
\text { Months from } 15 y\end{array}$ & $\begin{array}{l}\text { e of } 15+\text { years } \\
\text { to entry to } 1 \text { st union } \\
\text { Conceiving before }\end{array}$ & $\begin{array}{l}\text { Russians after entry to } 1^{\text {st }} \text { cohabitation } \\
\text { Months from } 1^{\text {st }} \text { cohabitation to } 1^{\text {st }} \text { marriage } \\
\text { y to analyzed union }\end{array}$ \\
\hline
\end{tabular}

In the situation, when the marriage was after the experience of cohabitation, conception (marked in yellow) happened strictly between marriage and 
cohabitation (even if it was the cohabitation of second order). Specification of Models 3, 4 and 5 are presented in Table 6.

\section{The results of the analysis of the second group of models}

In order to evaluate the role of conception in the process of forming matrimonial unions, three Cox regressions were constructed for each database. Due to the small number of events that match the specified trajectory, the Cox regressions built for Models 3, 4 and 5 turned out to be low in quality, so the detailed results are not given. However, significant results were aggregated, analyzed and presented in the form of schemes (Figures 5 and 6).

According to all three models built for GGS (Figure 5), it was found that conception stimulated the beginning of 20 per cent of first cohabitations, 23 per cent of first marriages and 16 per cent of marriages after the experience of living together. According to the regression coefficients, those couples in which conception happened have 4 times higher likelihood to enter into a cohabitation and a 3 times higher probability to enter into a marriage as first union than the couples without conception before entry into any union. In Model 3 (marriage after cohabitation), the significance of the coefficient is much greater than 5 per cent, so it is not conception, but other factors stimulate the entry into a such marriage.

Figure 5. The role of conception in the process of entering into unions of various types (GGS)

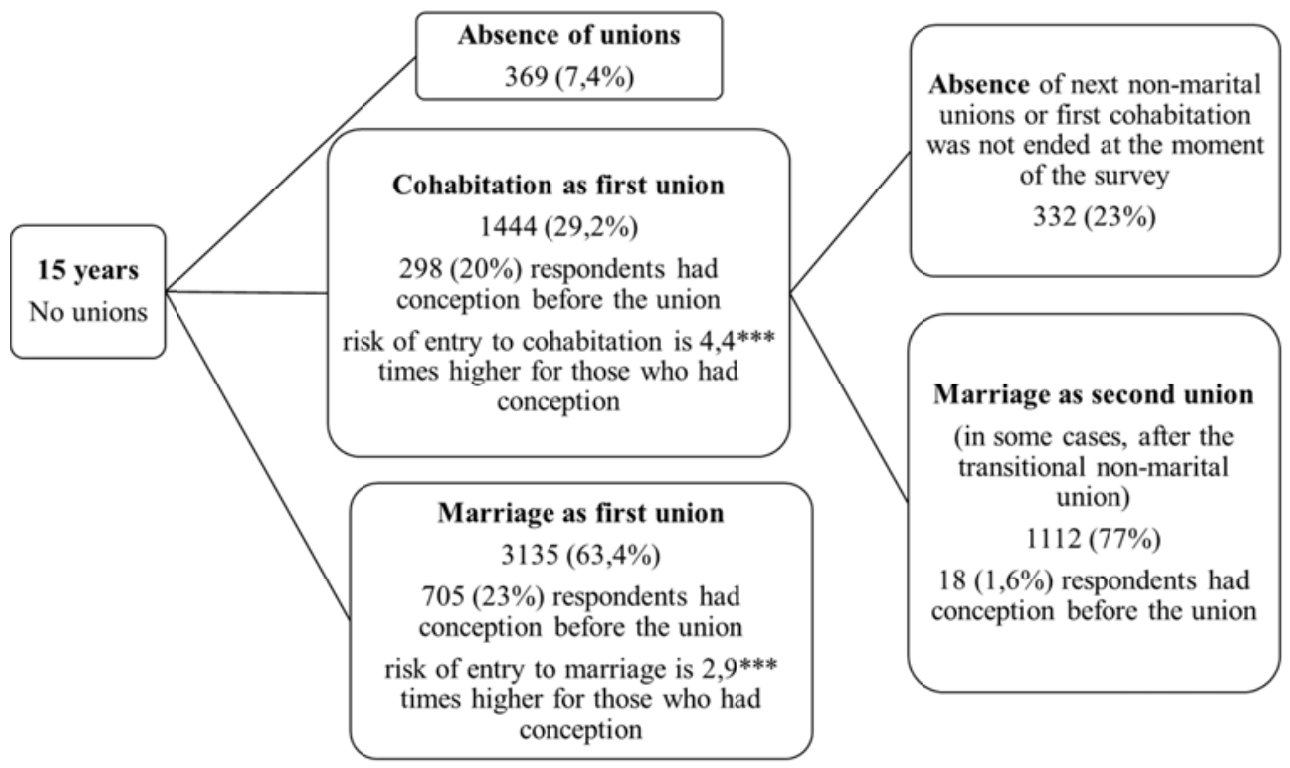

According to the PFS survey (Figure 6), a conception stimulated the beginning of 6.9 per cent of cohabitations as first union, 21 per cent of marriages as first union and 6 per cent of marriages after the experience of living together. The difference in the survey of stimulated marriages is only 2 per cent from GGS. The difference of such cohabitations in PFS is almost 3 times less, and that of marriages after the experience of living together is 2.6 times less. This means that, in the GGS sample, where more mature individuals were presented, cohabitation has proved itself to be suitable for raising children - almost on a par with marriage. In the PFS sample, that represents young generation, there are more respondents who, in case of birth of children, had more official relationships than in the GGS sample. This step could act as a guarantee of the seriousness of young people for their partners. 
Figure 6. The role of conception in the process of entering into unions of various types (PFS)

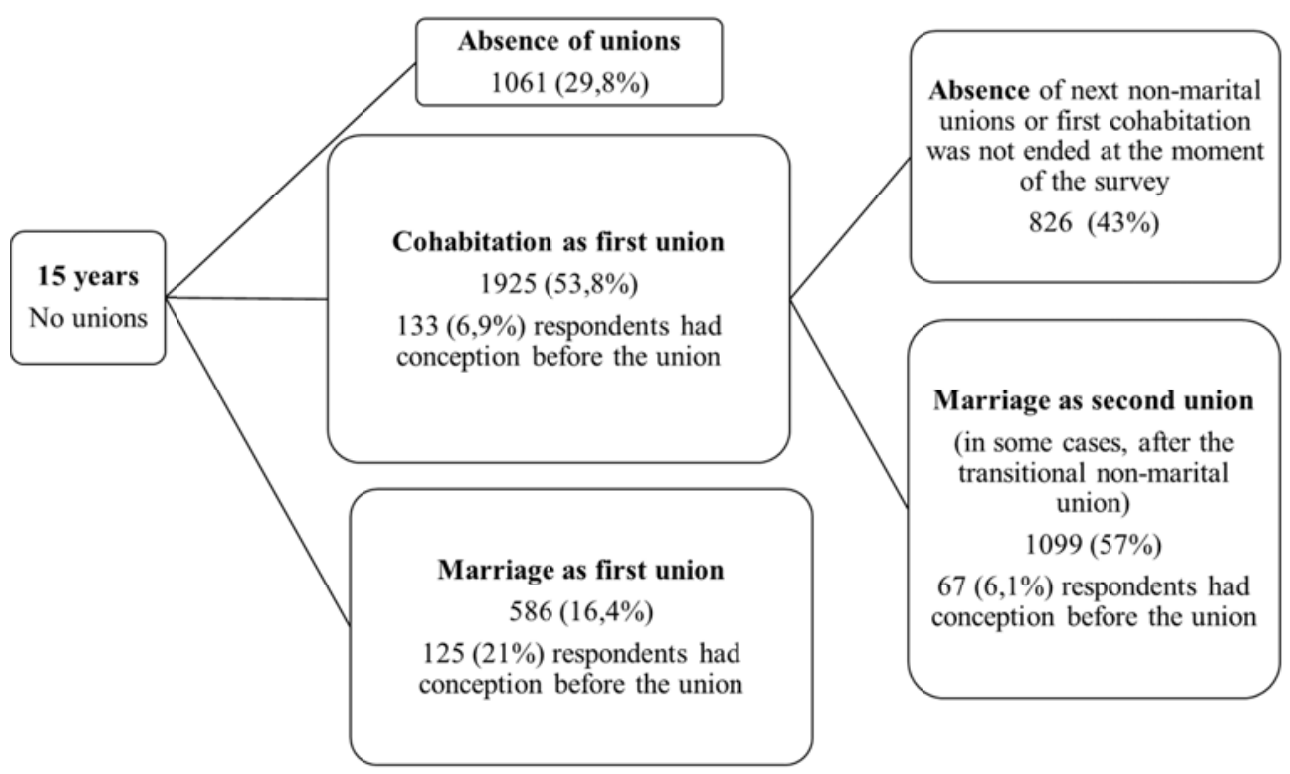

\section{The aggregated family formation trajectories}

In the Sequence Analyses, ${ }^{4}$ we constructed chronograms for matrimonial and reproductive events of both surveys. In order to trace the transitions between different events, we added the second unions. This allowed us not only to capture the typical statuses of life of the respondents, but also to notice the difference in the behaviours of representatives of different generations.

In Figure 7, we see the distribution of partnerships and fertility statuses of respondents over generations. On the horizontal axes of the chronograms are the ages of the respondents between 15 and 35 years. The youngest respondents have not yet reached the upper age limit, therefore, in the case of modern generations we had to work with censored data (indicated in grey). On the vertical axes the proportions of individuals belonging to each state at a given age are shown.

These chronograms show that singlehood, to which can be referred to as actual solitude or Living Apart Together is the most frequent state at the age of 15 . Marriage and marriage with conceptions are dominant statuses for Russians at the end of the age window. The frequency of these statuses by the age of 35 gradually decreases during the transition from Soviet to post-Soviet generations, giving a place to those who raise children while single or in the second marriage. The traditional form of matrimonial behaviour gives way to the other sequences, which confirms the assumption of de-institutionalized life courses.

4 We used the R package TraMineR (Gabadinho et al. 2011). 
Figure 7. Distribution of partnerships and fertility statuses by generation

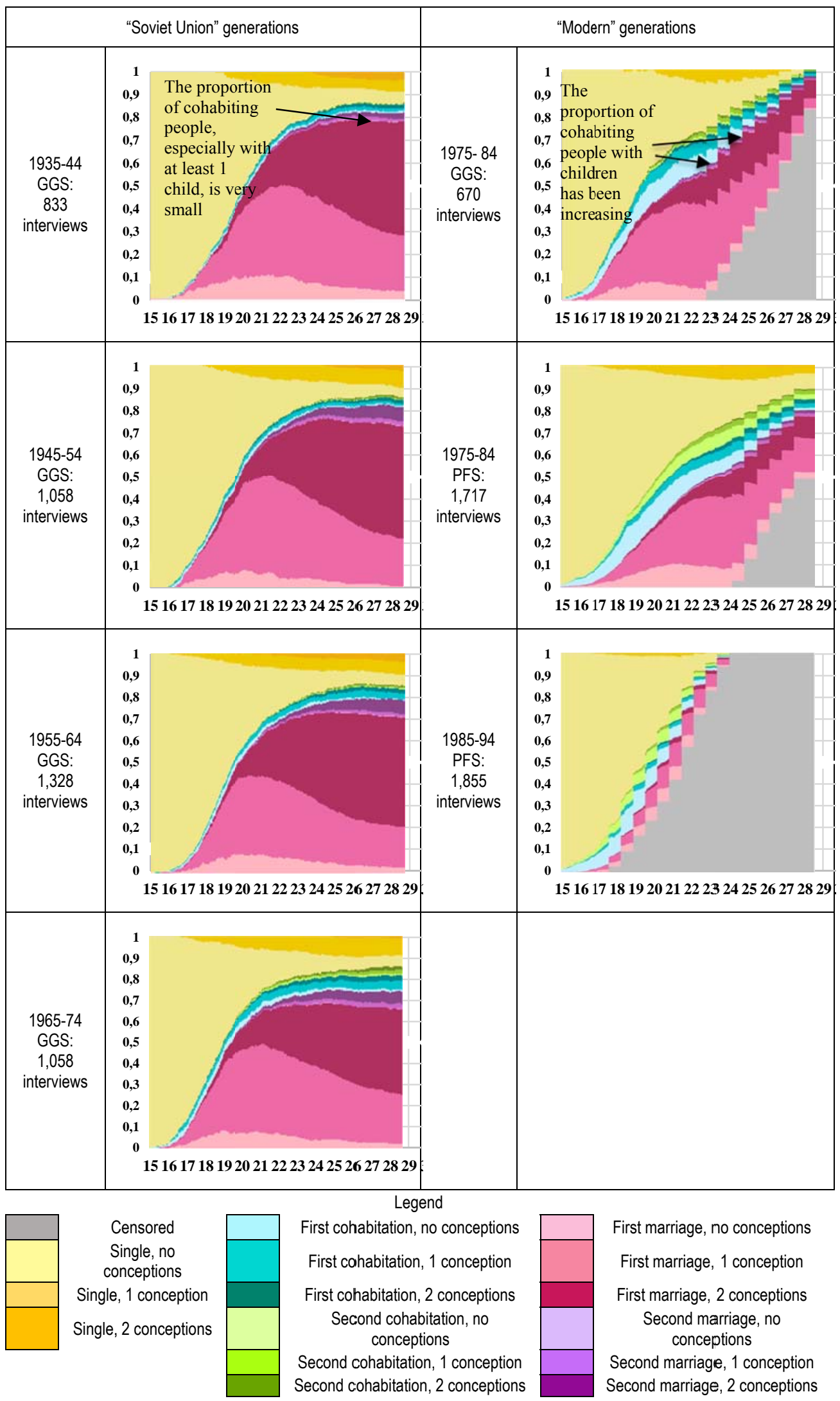

Statuses stand out when marriage is preceded by one or two cohabitations (cohabitation as a trial marriage), and also an interlayer of those who have never 
been married and had one or two conceptions in the first or second cohabitation (cohabitation as an independent union). Such interlayers are becoming increasingly visible for each subsequent generation, and thus, the spread of cohabitation is gradually moving from the stage of promotion to the stage of legitimation.

\section{Conclusions}

The aim of this study was to identify factors of entry into the first cohabitation, compare them with the factors of entry into the first marriage, determine the stage of the spread of cohabitation in Russia and, finally, demonstrate that policymakers should stop ignoring this phenomenon.

Not all of our hypotheses were confirmed.

1. For the Soviet generations (GGS data), women from 1965-74, those who received secondary or vocational education, urban residents and non-religious people are more likely to enter into cohabitation as a first union. The probability of entry into marriage as a first union is loosely associated with the level of education. The chance is higher for women, religious people and those who live in rural areas. For modern generations (PFS data), the probability of entering into unions of various types are associated only with gender (females are more likely to enter into any matrimonial unions), level of education (people with vocational education are more likely to engage in cohabitation than in marriage) and religiosity in a situation of marriage (the risk of marriage is higher for the religious than for the nonreligious).

2. Conception often precedes cohabitation and marriage as first unions, but does not act as a strong incentive for transition from cohabitation to marriage.

3. There are respondents with children (had at least one conception) in cohabitation in the samples of the surveys. Sequence analysis has revealed that the most frequent status for all generations by the age of 35 is "married, was conceived". Besides such states as "raising one or two children", "alone" or "in cohabitation" are becoming more common for the representatives of the modern generations by the end of the observed age. In these cases cohabitation is an alternative to marriage.

The modern generations begin their matrimonial biographies with cohabitation as a union, involving a lower degree of responsibility than marriage, but at the same time having the benefits of marriage (e.g. general budget, housing), which is especially important in a period of uncertainty. The changing of norms and values in the modern world leads to the fact that people consider religious, social and family traditions to be less important than before, starting to shape and fill their life courses based on their own priorities. Therefore, young, urban, non-religious, lesseducated people are considered to be the engine of change in the matrimonial field in Russia, confirming once more that cohabitations in Russia are more associated with the less-educated as opposed to Western European countries where the highly-educated are significantly more likely to follow long term cohabitation trajectories (Mills et al. 2013).

In modern Russian society, forms of marital partnership and reproductive behaviour are becoming more diverse and unpredictable. A standardized sequence of events in individual biographies is replaced by a variety of life courses, in which cohabitation becomes one of the options: cohabitations in Russia gradually have come to the stage of legitimation.

Policy-makers should treat the new institution as a decision of the people. An important question arises: why do people choose cohabitations instead of marriages? This question is for further studies, but what we know now for sure is 
that cohabitations are gaining power and popularity, and we cannot ignore them anymore.

\section{Acknowledgements}

The article was prepared within the framework of the Academic Fund Program at the National Research University Higher School of Economics (HSE) in 2016 (grant № 16-05-0011) and supported within the framework of a subsidy granted to the HSE by the Government of the Russian Federation for the implementation of the Global Competitiveness Program.

The authors also want to thank some colleagues who contributed in this paper. Heartfelt gratitude to Sergey V. Zakharov for a permanent scientific advising, insightful recommendations and openness to new ideas. Sincere thanks to Francesco C. Billari and Melinda Mills for the revision of our work in Life Course methods. A lot of thanks to Philippe Blanchard, Roxana Leu, Alla O. Tyndik, and Svetlana S. Biryukova for their consultations on Sequence Analysis. Finally, thanks to Vladimir A. Kozlov and Thomas H. Espy for their consulting on politics and inestimable help in the preparation of this paper.

\section{References}

Avdeev, Alexandre, Monnier, Alain (2000) 'Marriage in Russia: A Complex Phenomenon Poorly Understood', Population: An English Selection 12: 7-49.

Billari Francesco C. (2001) 'Sequence Analysis in Demographic Research. Special Issue on Longitudinal Methodology', Canadian Studies in Population 28(2): 439458.

Gabadinho, Alexis, Gilbert Ritschard, Nicholas S. Müller and Mathia Studer (2011) 'Analyzing and visualizing state sequences in $\mathrm{R}$ with TraMineR', Journal of Statistical Software 40(4): 1-37.

Gerber, Theodore P. and Danielle Berman (2010) 'Entry to Marriage and Cohabitation in Russia, 1985-2000: Trends, Correlates, and Implications for the Second Demographic Transition: La mise en couple en Russie, 1985-2000: tendances, facteurs associés et implications par rapport à la seconde transition démographique', European Journal of Population-Revue Europeenne de Demographie 26(1): 3-31.

Giddens Anthony (2003) Runaway World: How Globalization is Reshaping Our Lives, London: Profile Books Ltd.

Kaa, Dirk J. van de (1987) 'Europe's Second Demographic Transition', Population Bulletin 42(1): 3-57.

Kaa, Dirk J. van de and Ron Lesthaeghe (1986) 'Two Demographic Transitions?', Population: Growth and Decline 9-24.

Lesthaeghe, Ron (1995) The Second Demographic Transition in Western countries: An interpretation, in: Gender and Family Change in Industrialized Countries, Oxford: Clarendon Press.

Lesthaeghe Ron and Karel Neels (2002) 'From the First to the Second Demographic Transition: An Interpretation of the Spatial Continuity of Demographic Innovation in France, Belgium and Switzerland European', Journal of Population 18(4): 325-360.

Levada, Yu. (2005) 'Generations of XX Century: Opportunities of Studies' in Yu Levada , T. Shanin (Eds) Fathers and Children: Analysis of Contemporary Russian Generations. Moscow: Novoe Literaturnoe Obozrenie, pp. 39-60. 
Matysiak Anna (2009) 'Is Poland really 'immune' to spread of cohabitation?', Demographic Research 21(8): 215-234.

Mayer, Karl U. (2004) 'Whose Lives? How History, Societies, and Institutions Define and Shape Life Courses', Research in Human Development 1(3): 161-187.

Mills, Melinda (2004) 'Stability and change: the structuration of partnership histories in Canada, the Netherlands, and the Russian Federation', European Journal of Population Revue Europeenne de Demographie 20(2): 141-175.

Mills, Melinda and Blossfeld, Hans P. (2013) 'The Second Demographic Transition Meets Globalization: A Comprehensive Theory to Understand Changes in Family Formation in an Era of Rising Uncertainty', Life Course Research and Social Policies 1(1): 9-33.

Mills, Melinda, Laurent Lesnard and Gina Potarca (2013) 'Family Formation Trajectories in Romania, the Russian Federation and France: Towards the Second Demographic Transition?', European Journal of Population 29(1): 69-101.

Mitrofanova, Ekaterina S. (2013) 'Demographic behavior of Russians: family and fertility patterns across generations', Macrotheme Review 2(3): 71-80.

Philipov, Dimiter and Aiva Jasilioniene (2008) 'Union formation and fertility in Bulgaria and Russia: A life table description of recent trends', Demographic Research 19: 2057-2114.

Sobotka, Tomas and Laurent Toulemon (2008) 'Overview Chapter 4: Changing family and partnership behaviour: Common trends and persistent diversity across Europe', Demographic Research 19(6): 85-138.

Vikat, Andrés, Zsolt Spéder, Gijs Beets, Francesco C. Billari, Christoph Bühler, Aline Désesquelles, Tineke Fokkema, Jan M. Hoem, Alphonse MacDonald and Gerda Neyer (2008) 'Generations and Gender Survey (GGS): Towards a better understanding of relationships and processes in the life course', Demographic Research 17: 389-440.

Vishnevsky, Anatoly G. (2009) 'A new stage of Russian demographic development', in Vishnevsky, A. G. and S.N. Bobilev (Eds.) Russia Facing Demographic Challenges. National Human Development Report Russian Federation, Moscow, pp. 18-25.

Zakharov, Sergei (2008) 'Russian Federation: From the first to Second Demographic Transition', Demographic Research 19, 907-972. 